\title{
Tax evasion and work in the underground sector
}

\author{
Anders Frederiksen ${ }^{\mathrm{a}}$, Ebbe Krogh Graversen ${ }^{\mathrm{b}}$, Nina Smith ${ }^{\mathrm{a}, *}$ \\ ${ }^{\mathrm{a}} I Z A$, CIM and Department of Economics, Aarhus School of Business, Prismet, Silkeborgvej 2, \\ DK-8000 Aarhus C, Denmark \\ ${ }^{\mathrm{b}}$ CIM, CLS and The Danish Centre for Studies in Research and Research Policy, Finlandsgade 4, \\ DK-8200 Aarhus N, Denmark
}

Received 30 August 2002; accepted 11 February 2004

Available online 2 July 2004

\begin{abstract}
A bivariate random effect panel data model is estimated for male labour supply in the taxable and the non-taxable sectors in Denmark. The wage rates and non-labour income have significant effects on labour supply in both sectors. The average own wage elasticity with respect to underground labour supply is found to be small, 0.02 , while the cross price elasticity from regular wages is larger, -0.52 . Simulations of potential tax reforms show that a reduction of the marginal taxes has minor effects on male labour supply to the untaxed sector, while the effect on male labour supply to the taxed sector is larger.

(C) 2004 Elsevier B.V. All rights reserved.
\end{abstract}

JEL classification: $\mathrm{C} 33 ; \mathrm{C} 34 ; \mathrm{H} 26 ; \mathrm{J} 22$

Keywords: Labour supply; Tax evasion; Censored bivariate panel data model

\section{Introduction}

It is commonly expected that taxes have an effect on the leisure-labour choice. Normally, it is also assumed that labour income taxes stimulate labour market activities in the untaxed sectors of the economy through tax evasion. Despite the fact that many theoretical investigations of this assumption exist, there are relatively few

\footnotetext{
* Corresponding author. Tel.: +45 8948 6413; fax: +45 89486197.

E-mail addresses: afr@asb.dk (A. Frederiksen),ekg@cfa.au.dk (E.K. Graversen), nina@asb.dk (N. Smith). 
empirical analyses of labour supply to the untaxed "underground" sector. ${ }^{1}$ The lack of data on labour supply and wage rates in the underground sector is the major reason for this. In this paper, we have access to a unique database which consists of a panel survey sample with information on hours of work and wages in the untaxed sector. This information is merged to extensive information from administrative registers. The labour supplies to the taxed and untaxed sectors are modelled jointly, and the model is estimated for male Danish workers who, due to the high Danish tax pressure and the tax structure, face relatively high marginal tax rates on wage income compared to workers in most other countries.

One of the first papers discussing underground labour supply is the theoretical paper by Allingham and Sandmo (1972). Since then, several other models of tax evasion have appeared. $^{2}$ They typically combine conventional labour supply theory with a standard portfolio model, i.e. how much labour to supply all in all and how much in each sector. We pursue this way of modelling and set up a model where individuals choose the labour supply in the two sectors given a known tax rate on the regular labour income, i.e. the regular sector net wage rate, and a known gross wage rate in the underground sector. Based on this model, we estimate the incentive effect of regular sector income taxes on regular as well as underground labour supply.

The survey information consists of two successive waves in 1994 and 1996 which are merged with register information on non-labour income and background characteristics of the individuals stemming from administrative registers from Statistics Denmark. Based on self-reported labour supply and wage rate measures in the regular and in the underground sectors, we estimate a random effect bivariate Tobit model on the labour supply in both sectors. Thus, we can control for permanent individual-specific effects and transitory random errors in and between the two sectors.

The results show that regular sector wage rates and non-labour income have significant effects on labour supply in both sectors so income taxes seem to twist the labour supply away from taxed regular to untaxed underground supply. We also find a significant permanent individual-specific effect. For the untaxed labour supply, the cross wage elasticity varies considerably across groups, the highest average cross wage elasticities are found for men who also work in the regular (taxed) sector.

In Section 2, we introduce a theoretical model similar to that of Cowell (1985) and develop it further to our purpose. In Section 3, we introduce the empirical specification and the estimation strategy for the econometric model. In Section 4, we present the panel survey data set together with some descriptive and preliminary analysis. The estimation results and the results from two reforms of the tax system are presented in Sections 5 and 6. Finally, Section 7 concludes the paper.

\footnotetext{
${ }^{1}$ Among these studies are Lemieux et al. (1994) and Lacroix and Fortin (1992) for Canada, Isachsen et al. (1985) for Norway, van Eck and Kazemier (1988) for the Netherlands and Wolff (1990) for Germany. Only the Canadian studies estimate the joint labour supply in the regular and the underground sectors.

${ }^{2}$ See for example Feige (1989) and Cowell (1990) for a collection of contributors in the field. Schneider and Enste (2000) give a recent survey on theories and evidence of shadow economies.
} 


\section{The model}

The labour market can be modelled by a two-sector model where total time is spent on leisure, work in the regular sector, R, or work in the underground sector, U. In this two-sector model, the individual faces two simultaneous problems: (1) a conventional leisure-labour choice and (2) an optimal allocation problem of total working time between regular and underground activities. We set up a system of contemporary labour supply equations for the regular and underground sectors based on the theoretical framework on tax evasion, see for example Cowell (1985). This gives a tax evasion model with endogenous income where a standard portfolio allocation model is combined with a conventional labour supply model. ${ }^{3}$

The gross wage rates in the regular and the underground sectors are allowed to differ between the two sectors and are denoted $W_{\mathrm{R}}$ and $W_{\mathrm{U}}$, respectively. An individual faces a known tax rate, $t$, in the regular sector, and the net wage rate is $W_{\mathrm{R}}(1-t)$, where $W_{\mathrm{R}}$ is the gross wage rate in the regular sector. The tax rate is a function of labour and non-labour income in the regular sector solely, so the tax burden can be reduced by work in the underground sector. In the underground sector, there is a risk of being detected by the tax authorities. The probability or risk of being detected by the tax authorities is assumed to increase as a function, $p(.,$.$) , of hours worked in the underground sector, h_{\mathrm{U}}$, and a vector of other characteristics, $x$. The penalty rate in case of detection is $\theta>t$, and the expected penalty is increasing in the unreported income, i.e. the expected tax rate in the underground sector equals $\theta p$. Thus, the gross wage rates in the underground sectors includes a premium proportional with the individual specific risk, and the net wage rate in the underground sector equals $W_{\mathrm{U}}(1-\theta)$ if detected by the tax authorities (with probability $p$ ) and $W_{\mathrm{U}}$ if not detected (with probability $(1-p)$ ).

This results in two consumption levels $C_{\mathrm{D}}$ and $C_{\mathrm{ND}}$ reflecting whether the individual is detected (D) or not (ND)

$$
\begin{aligned}
& C_{\mathrm{D}}=Y+W_{\mathrm{R}}(1-t) h_{\mathrm{R}}+(1-\theta) W_{\mathrm{U}} h_{\mathrm{U}} \\
& C_{\mathrm{ND}}=Y+W_{\mathrm{R}}(1-t) h_{\mathrm{R}}+W_{\mathrm{U}} h_{\mathrm{U}}
\end{aligned}
$$

where $C$ is the expected consumption at a numeraire price, $Y$ is the non-labour income net of taxes, and $h_{\mathrm{R}}$ and $h_{\mathrm{U}}$ are the hours supplied in the two sectors.

The individual faces different constraints on the number of hours to supply. Obviously, both $h_{\mathrm{R}} \geq 0$ and $h_{\mathrm{U}} \geq 0$. Furthermore, in usual studies with information on primary job solely, individuals may be underemployed in one or both sectors. However, we include information on primary and secondary jobs which allows us to ignore this latter possibility and assume that the hours can be chosen voluntarily by the individual. ${ }^{4}$ Hence, the only restrictions are the non-negativity restrictions, and we get a simple bivariate optimisation problem. For simplicity, we assume that the individual is an

\footnotetext{
${ }^{3}$ In the present model, individuals are the sample unit, and we do not have information allowing us to model a simultaneous household labour supply decision process. Thus, we assume the spouse's income to be part of the individual's non-labour income.

4 This Issue Series contrary to Lacroix and Fortin (1992) who allow for upper limit constraints in their model but use other simplifying assumptions in their empirical model, see later.
} 
expected-utility maximiser, as in Lemieux et al. (1994). Thus, we have the following maximising problem

$$
\max p \mathrm{U}\left(h_{\mathrm{R}}, h_{\mathrm{U}}, C_{\mathrm{ND}}\right)+(1-p) U\left(h_{\mathrm{R}}, h_{\mathrm{U}}, C_{\mathrm{D}}\right) \quad \text { s.t. }(1),(2), h_{\mathrm{R}} \geq 0, h_{\mathrm{U}} \geq 0
$$

The utility function, $\mathrm{U}(\cdot)$, is assumed to be strictly concave, increasing in $C$ and decreasing in $h_{\mathrm{R}}$ and $h_{\mathrm{U}}$ which may not necessarily be perfect substitutes, see for instance in Fortin et al. (1990) and Lacroix and Fortin (1992).

The first-order Kuhn-Tucker conditions to the problem are sufficient to characterize a unique optimum given the assumptions about $\mathrm{U}(\cdot)$ above and a strictly convex budget set. ${ }^{5}$ The first-order conditions of Eq. (3) define four states of labour supply. We denote state 1 as the state where the individual works in both sectors, $h_{\mathrm{R}}>0$ and $h_{\mathrm{U}}>0$. In state 2 , the individual works only in the regular sector, $h_{\mathrm{R}}>0$ and $h_{\mathrm{U}}=0$. In state 3 , the individual works only in the underground sector, $h_{\mathrm{R}}=0$ and $h_{\mathrm{U}}>0$. Finally, in state 4 , the individual does not work at all, so $h_{\mathrm{R}}=0$ and $h_{\mathrm{U}}=0$.

\section{Econometric specification}

The solution to Eq. (3) determines the labour supply functions to the regular and the underground sectors, $h_{\mathrm{R}}(\cdot)$ and $h_{\mathrm{U}}(\cdot)$. The functional forms of the two labour supply functions depend of the specification of the utility function. For simplicity, we have chosen a linear empirical specification for both of these supply functions, see Hausman and Ruud (1984) for a theoretical justification of this specification. The linear form is preferred because it simplifies the empirical model considerably. ${ }^{6}$

The latent joint estimation model is

$$
\begin{aligned}
& h_{\mathrm{R} i t}^{*}=x_{\mathrm{R} i t} \beta_{\mathrm{R}}+\mu_{\mathrm{R} i}+\epsilon_{\mathrm{R} i t} \\
& h_{\mathrm{U} i t}^{*}=x_{\mathrm{U} i t} \beta_{\mathrm{U}}+\mu_{\mathrm{U} i}+\epsilon_{\mathrm{U} i t}
\end{aligned}
$$

for individual $i=1, \ldots, N$ and time period $t=1,2 . h_{\mathrm{R} i t}$ the latent labour supply is in the regular sector, $h_{\mathrm{U} i t}^{*}$ the latent labour supply is in the underground sector. $x_{\mathrm{Rit}}$ and $x_{\mathrm{Uit}}$ are observed time varying explanatory variables explaining the deterministic part of the labour supply in the two sectors. $\mu_{\mathrm{R} i}$ and $\mu_{\mathrm{U} i}$ are permanent individual-specific effects, and $\epsilon_{\mathrm{Rit}}$ and $\epsilon_{\mathrm{Uit}}$ are transitory random errors capturing optimization errors.

The observed labour supply to the regular and underground sectors equals $h_{\mathrm{R} i t}=\max \left(0, h_{\mathrm{R} i t}^{*}\right)$ and $h_{\mathrm{U} i t}=\max \left(0, h_{\mathrm{U} i t}^{*}\right)$. Hence, we have to estimate a panel data bivariate Tobit model with both transitory and permanent individual effects. ${ }^{7}$ The

\footnotetext{
5 This corresponds to the assumption that the tax system is strictly concave in hour of work.

${ }^{6}$ Graversen (1998) analyses the sensitivity of the assumptions concerning functional form in different models of labour supply. Among others he uses a flexible functional form introduced by Duncan (1990), which allows for backward bending supply functions. However, the models showed little support for backward bending supply in Denmark.

${ }^{7}$ This corresponds to an extension of the type 3 Tobit model in Amemiya (1985). An econometric specification similar to ours is used in Hassink and van Ours (1995) among others.
} 
permanent individual-specific effect and the transitory error term are assumed to be bivariate normal distributed with means zero, variances $\tau^{2}$ and $\sigma^{2}$ and correlation $\rho$, respectively, i.e., $\left(\mu_{\mathrm{R}}, \mu_{\mathrm{U}}\right) \sim \Phi_{2}\left(0,0, \tau_{\mathrm{R}}^{2}, \tau_{\mathrm{U}}^{2}, \rho_{\mu}\right)$ and $\left(\epsilon_{\mathrm{R}}, \epsilon_{\mathrm{U}}\right) \sim \Phi_{2}\left(0,0, \sigma_{\mathrm{R}}^{2}, \sigma_{\mathrm{U}}^{2}, \rho_{\epsilon}\right)$. The correlation between the permanent and the transitory effect is set to zero. Hence, the likelihood contribution for each individual can be written as: ${ }^{8}$

$$
\begin{aligned}
& \mathscr{L}_{i}=\int_{-\infty}^{\infty} \int_{-\infty}^{\infty} \prod_{t=1}^{T}\left[\Phi_{2}\left(\frac{-\beta_{\mathrm{R}}^{\prime} x_{\mathrm{R}}-\mu_{\mathrm{R}}}{\sigma_{\mathrm{R}}}, \frac{-\beta_{\mathrm{U}}^{\prime} x_{\mathrm{U}}-\mu_{\mathrm{U}}}{\sigma_{\mathrm{U}}}, \rho_{\epsilon}\right)\right]^{\left(1-I_{t_{R}}\right)\left(1-I_{\mathrm{t}_{\mathrm{U}}}\right)} \\
& *\left[\Phi\left(\frac{\frac{-\beta_{\mathrm{R}}^{\prime} x_{\mathrm{R}}-\mu_{\mathrm{R}}}{\sigma_{\mathrm{R}}}-\rho_{\epsilon} \frac{h_{\mathrm{U}}-\beta_{\mathrm{U}}^{\prime} x_{\mathrm{U}}-\mu_{\mathrm{U}}}{\sigma_{\mathrm{U}}}}{\sqrt{1-\rho^{2}}}\right) \phi\left(\frac{h_{\mathrm{U}}-\beta_{\mathrm{U}}^{\prime} x_{\mathrm{U}}-\mu_{\mathrm{U}}}{\sigma_{\mathrm{U}}}\right) \frac{1}{\sigma_{\mathrm{U}}}\right]^{\left(1-I_{\mathrm{R}_{\mathrm{R}}}\right) I_{t_{\mathrm{U}}}} \\
& *\left[\Phi\left(\frac{\frac{-\beta_{\mathrm{U}}^{\prime} x_{\mathrm{U}}-\mu_{\mathrm{U}}}{\sigma_{\mathrm{U}}}-\rho_{\epsilon} \frac{h_{\mathrm{R}}-\beta_{\mathrm{R}}^{\prime} x_{\mathrm{R}}-\mu_{\mathrm{R}}}{\sigma_{\mathrm{R}}}}{\sqrt{1-\rho^{2}}}\right) \phi\left(\frac{h_{\mathrm{R}}-\beta_{\mathrm{R}}^{\prime} x_{\mathrm{R}}-\mu_{\mathrm{R}}}{\sigma_{\mathrm{R}}}\right) \frac{1}{\sigma_{\mathrm{R}}}\right]^{I_{t_{\mathrm{R}}}\left(1-I_{t_{\mathrm{U}}}\right)} \\
& *\left[\phi_{2}\left(\frac{h_{\mathrm{R}}-\beta_{\mathrm{R}}^{\prime} x_{\mathrm{R}}-\mu_{\mathrm{R}}}{\sigma_{\mathrm{R}}}, \frac{h_{\mathrm{U}}-\beta_{\mathrm{U}}^{\prime} x_{\mathrm{U}}-\mu_{\mathrm{U}}}{\sigma_{\mathrm{U}}}, \rho_{\epsilon}\right) \frac{1}{\sigma_{\mathrm{R}} \sigma_{\mathrm{U}}}\right]^{I_{\mathrm{R}} I_{t_{\mathrm{U}}}} \\
& * \phi_{2}\left(\frac{\mu_{\mathrm{R}}}{\tau_{\mathrm{R}}}, \frac{\mu_{\mathrm{U}}}{\tau_{\mathrm{U}}}, \rho_{\mu}\right) \frac{1}{\tau_{\mathrm{R}} \tau_{\mathrm{U}}} \mathrm{d} \mu_{\mathrm{R}} \mathrm{d} \mu_{\mathrm{U}}
\end{aligned}
$$

$\Phi_{2}$ and $\phi_{2}$ are the bivariate normal distribution and density functions, while $\Phi$ and $\phi$ are the univariate normal distribution and density functions. $I_{t \mathrm{R}}$ and $I_{t \mathrm{U}}$ are dummy variables which equal one if the individual works in the regular or the underground sector, respectively, in period $t$. Otherwise, $I_{t \mathrm{R}}$ and $I_{t \mathrm{U}}$ are zero.

Before we maximize the likelihood function in Eq. (5), we have to deal with two standard problems in labour supply studies. Firstly, the usual missing value problem for the unobserved wage rates also applies to this study. The problem exists for both sectors since there are nonparticipants in both sectors. Therefore, we estimate selectivity-corrected gross wage rates for the two sectors as well as the net wage rate in the regular sector. The gross wage functions include the variables experience, length of education, tenure, age, occupational categories, individual annual unemployment rate and regional indicators, while the probit model used to calculate the selection term includes demographic and household characteristics, in order to secure identification. The marginal tax rate in the regular sector is calculated from register information on the individual's tax payment for the respective years. Hence, the calculated marginal tax rate almost exactly equals the true marginal tax rate. In the labour supply estimations, predicted wage rates are used in both sectors. ${ }^{9}$

Secondly, we linearise the piecewise linear budget constraint in the regular sector around the observed labour supply in order to avoid the problem of kinks on the budget

\footnotetext{
${ }^{8}$ The empirical sample is corrected for non-response and stratification in the data collection, i.e. each individual's contribution to the log likelihood function is weighted in order to make the maximisation problem representative for the population defined in Section 4.

${ }^{9}$ The results from these estimations are not shown here but they are available on request from the authors.
} 
constraints. We assume that the gross wage rates are exogenous to the hours worked and we use predicted net wage rate from the wage regression for all individuals in order to avoid the endogeneity problem caused by the progressive taxes. The virtual income in the regular sector is found using conventional methods, as the virtual consumption is found from a linearisation of the budget segment on which the individual is observed.

\section{Data description and preliminary analysis}

The data used in this paper originate from two successive surveys. The first wave was performed in the fourth quarter of 1993 and the first quarter of 1994 while the second wave was performed in the first two quarters of 1996 . Approximately $75 \%$ of the individuals in the first wave were reinterviewed in the second wave, so we have an unbalanced panel. New individuals are sampled for the second wave in order to keep the sample size approximately constant. The survey information is supplemented with register information from administrative data on all individuals in the sample for the years 1992 1994. ${ }^{10}$

The sample is restricted to men aged 18 or more in 1994. In the other end, we restrict the sample to individuals aged less than 60 years because early retirement is widespread from the age of 60 due to the 'post employment wage scheme', which is an early retirement scheme open to about $80 \%$ of the labour force members when they pass the age of 60 . We also exclude women from the sample because a large proportion of the female untaxed labour supply consists of informal childcare taking place at home. The calculated wage rates for these activities are very low, see Pedersen and Smith (1998), probably because this type of work often allows the person to do other household tasks or combine childcare with leisure activities. Further, self-employed individuals are excluded from the analysis because we do not have enough information in order to calculate their taxes, wage rates or disposable incomes exactly. Self-employed are allowed to choose between normal taxation for employed persons or be taxed according to the totally different 'firm tax system' (virksomhedsskatteordningen). We have no information on which tax scheme the self-employed person has chosen, and thus, we are not able to include them in the model. The group self-employed is relatively small (about $6 \%$ of the population) but they tend to work more in the untaxed sector than other groups, although this tendency is not statistically significant, see Pedersen and Smith (1998). Finally, we have excluded individuals on social welfare and social pensions from the analysis. This is partly because of data restrictions since we are not able to calculate disposable income and taxes for social welfare recipients, and partly because their labour supply incentives may be very different from the rest of the population.

\footnotetext{
${ }^{10}$ The survey used in this study was a supplement to the regular labour force surveys, LFS, collected by Statistics Denmark in 1994 and 1996. The Rockwool Research Foundation financed a number of supplementary survey questions, mainly on labour supply and wages which were added to the labour force survey.
} 
Table 1

Sample distribution on the four regimes, 1994 and 1996 (percent)

\begin{tabular}{llllll}
\hline Year & State $1, h_{\mathrm{R}}>0, h_{\mathrm{U}}>0$ & State $2, h_{\mathrm{R}}>0, h_{\mathrm{U}}=0$ & State $3, h_{\mathrm{R}}=0, h_{\mathrm{U}}>0$ & State $4, h_{\mathrm{R}}=0, h_{\mathrm{U}}=0$ & Total \\
\hline 1994 & 19 & 69 & 1 & 11 & 100 \\
1996 & 29 & 64 & 2 & 5 & 100 \\
\hline
\end{tabular}

The information on weekly hours in the regular sector is survey-based. Weekly hours are defined as the normal weekly hours in main occupation and second job. Thus, overtime hours are included if it occurs on a regular basis. ${ }^{11}$ Unemployed individuals on unemployment benefits are included in the sample, and their labour supply to the regular sector is set to zero.

There may be more definitions of labour supply to the underground economy, among other things depending on the tax rules in the country concerned. In Denmark, labour supply in the underground economy includes a number of untaxed activities. In order to help the interview persons to give correct and valid answers to the question on tax evasion, all interview persons have got the following description of what is considered to be work in the underground sector according to the Danish tax rules: ${ }^{12}$ "A number of things indicate that it is commonly accepted in the population to supply labour to the underground sector, i.e. to perform activities which are not registered by the tax authorities, and where the 'participants', both buyer and seller, benefit because they do not pay taxes or VAT. It may be untaxed activities where there is a cash payment or it may be exchanges of goods and services between friends or family members. Have you during the latest year performed any of these activities?"

If the interview person answers positively to this question, he is also asked about the hours worked and the hourly wage rate in the underground sector. The majority of those with a positive underground labour supply are able to give information on hourly wage rates in the underground economy, but a number of individuals instead give information on the total income received in the untaxed sector during the latest year or month and the average number of hours worked during that period. Based on this information, we calculate average hourly wage rates. Table 1 shows the distribution of the sample in the four states defined in Section 2 in the two survey years 1994 and 1996. The majority of individuals are in state 2 and are only observed working in the regular sector. Among those who work in the untaxed sector, the majority also have a job in the regular sector.

Table 2 further shows the average weekly labour supply and hourly wages in the two sectors. The participation rate in both sectors increased from 1994 to 1996 . This partly reflects the cyclical upturn which started early in 1994 in Denmark. The weekly number of hours, conditional on participation, also increased in the regular sector but not in the

\footnotetext{
11 The survey includes information for the 1996 wave on overtime hours during the week before the survey week. Since we do not have information on overtime work in 1994, and since our measure of the untaxed labour supply is based on information on average (weekly) work during the latest year, we prefer to use a parallel measure for labour supply to the taxed sector, and therefore we use the 'normal hours' in main occupation and second jobs.

${ }^{12}$ The first sentence in the question also has the purpose to increase the response rate in survey.
} 
Table 2

Means and standard deviations of hours, earnings and wage rates in the regular and the underground sectors

\begin{tabular}{lccccc}
\hline & \multicolumn{3}{l}{ Regular sector } & & \multicolumn{2}{l}{ Underground sector } \\
\cline { 2 - 3 } \cline { 5 - 6 } & 1994 & 1996 & & 1994 & 1996 \\
\hline Participation rate (1 if participation, 0 else) & 0.88 & 0.93 & & 0.20 & 0.31 \\
Weekly hours, given participation, $h \mid h>0$ & $39.4(7.0)$ & $39.0(6.8)$ & & $4.3(5.9)$ & $2.2(4.2)$ \\
Hourly wage rate $\left(W_{\text {gross }}\right)$, DKK, 1996 prices & $123.5(35.8)$ & $128.5(40.2)$ & & $84.0(15.4)$ & $84.8(17.0)$ \\
Hourly wage rate $\left(W_{\text {net }}\right)$, DKK, 1996 prices & $55.4(5.6)$ & $56.5(7.9)$ & & - & - \\
Weekly earnings $(Y)$ DKK, 1996 prices & $1959.8(769.0)$ & $2061.6(767.1)$ & $51.9(226.2)$ & $58.6(237.9)$ \\
Number of observations & 1348 & 1169 & 1348 & 1169 \\
\hline
\end{tabular}

Numbers in parenthesis are standard errors.

underground sector. In 1996, 31\% of the males in the selected sample had been active in the underground sector. However, the weekly hours in the underground sector are still relatively low compared to other countries. On average, the participants in the underground sector only worked 2-4 h weekly. Thus, for Danish men underground work in Denmark is typically a kind of untaxed "second" job or part-time job. It is very seldom a full-time job, contrary to some other countries, for instance Spain, where the employees often either work in the regular or in the underground sector, see Ahn and De la Rica (1997).

The gross wage rates in the regular sector are considerably higher than in the underground sector, see Table 2 and Fig. 1. On average, the gross wage in the underground sector was $66 \%$ of the wage in the regular sector for males. The underground gross wage rate is highly skewed with high frequencies in the lower end of the distribution, contrary to the regular sector gross wage distributions which are more symmetric although bimodal. The average net wage in the regular sector is considerably lower than the regular sector gross wage rate due to the high marginal tax rates and below the gross wage rate in the underground sector. ${ }^{13}$ Unfortunately, we do not have any information which allows us to identify the implicit tax rate in the underground sector, i.e. $\theta p$. For this sector we use the gross wage rate in the estimations.

The survey information is merged with extensive register information on different sources of income and tax allowances for the household which combined with the survey information on hourly wages allows us to construct relatively precise budget constraints for each individual in the chosen sample. ${ }^{14}$ All economic variables are reported in 1996 prices.

\section{Estimation results}

The estimation coefficients from the empirical model are given in Table 3 . The own net wage coefficients in the regular and underground sectors are positive but only significant

\footnotetext{
13 Thus, the averages are consistent with the thesis that there is a premium included in the gross wage rate in the underground sector, such that the expected marginal wage rate in this sector (theoretically) equals the marginal net wage rate in the regular sector. If no risk premium, everybody would (theoretically) work in the underground sector at a higher wage rate, at least until the wage rates are equalised through lower marginal tax rates on lower tax segment in the regular sector.

${ }^{14}$ The construction of budget constraint for the data set used in this study is discussed in more details in Frederiksen et al. (2001).
} 


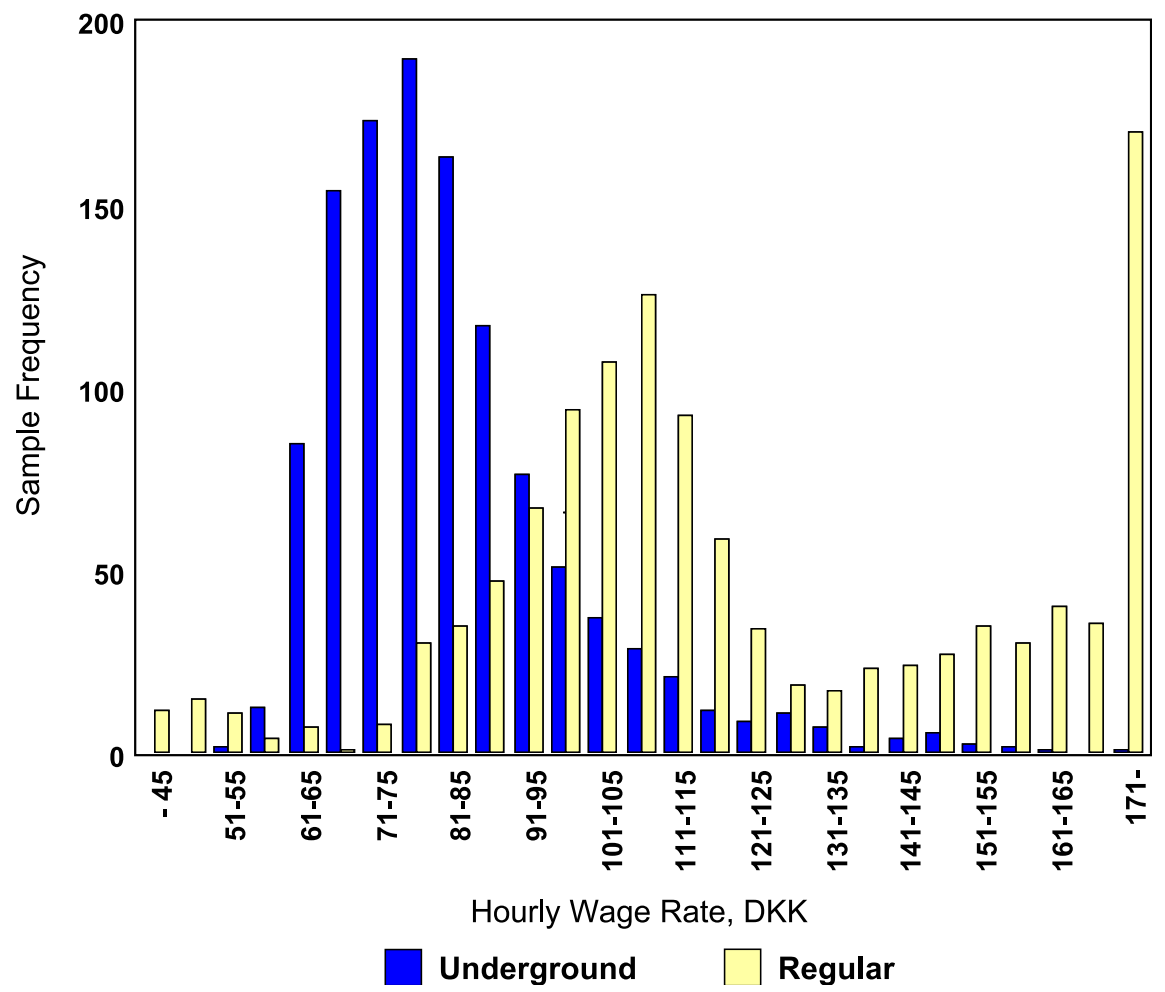

Fig. 1. Sample distributions by hourly gross wage rate (DKK, 1996 prices) in underground and regular sectors, 1996.

for the regular sector. The cross-price effects as well as the income effects are negative in both sectors. Thus, the empirical results are in line with prior expectations. Labour supply in the underground sector declines with age, contrary to labour supply in the regular sector. This may reflect that older people compared to younger people are more risk averse, and older people may also often have more to lose with respect to reputation in neighbourhood etc. Number and age of children do not seem to affect significantly the labour supply decision to the untaxed sector. The typical man working in the underground sector is a skilled (vocational training) or unskilled worker who is relatively young, and who obtains a relatively low wage in the regular sector.

Married or cohabiting men tend to work more in the regular sector relative to single persons, but also for the regular sector we find that the number or age of children does not have any significant effect on male labour supply. There seems to be no age effects in the regular sector given the present model setup. Several attempts have been made in identifying either a linear or a nonlinear relation between labour supply and age in the regular sector but without success.

The estimates of variation in the transitory error term and the permanent individualspecific effects, $\tau$ and $\sigma$, are shown in the last section of Table 3. The correlation 
Table 3

Estimation results (weekly hours)

\begin{tabular}{|c|c|c|}
\hline Explanatory variables & Coefficient & Standard error \\
\hline \multicolumn{3}{|l|}{ Regular sector } \\
\hline Constant & 12.771 & 1.934 \\
\hline Net wage rate, regular $\left(W_{\mathrm{R}, \text { net }} / 100\right)$ & 18.327 & 3.182 \\
\hline Weekly income/100,000 & -1.755 & 0.230 \\
\hline Gross wage rate, underground $\left(W_{\mathrm{U}, \text { gross }} / 100\right)$ & -0.034 & 1.210 \\
\hline Age & -0.011 & 0.026 \\
\hline Academic education & -0.181 & 0.635 \\
\hline Vocational education & -0.034 & 0.490 \\
\hline Married & 2.330 & 0.654 \\
\hline Cohabiting & 2.028 & 0.658 \\
\hline Owner of house & 0.437 & 0.522 \\
\hline Child aged $0-2$ years & 0.403 & 0.607 \\
\hline Child aged $3-6$ years & -0.443 & 0.679 \\
\hline Year $=1996$ & 1.297 & 0.322 \\
\hline \multicolumn{3}{|l|}{ Underground sector } \\
\hline Constant & -11.937 & 1.772 \\
\hline Net wage rate, regular $\left(W_{\mathrm{R}, \text { net }} / 100\right)$ & -8.028 & 3.180 \\
\hline Weekly income $/ 100,000$ & -0.460 & 0.245 \\
\hline Gross wage rate, underground $\left(W_{\mathrm{U}, \text { gross }} / 100\right)$ & 0.190 & 1.146 \\
\hline Age & -2.522 & 0.501 \\
\hline Academic education & -0.102 & 0.019 \\
\hline Vocational education & -0.089 & 0.360 \\
\hline Married & -0.520 & 0.584 \\
\hline Cohabiting & 0.337 & 0.562 \\
\hline Owner of house & 0.198 & 0.403 \\
\hline Number of children & 0.264 & 0.192 \\
\hline Year $=1996$ & 2.539 & 0.315 \\
\hline Transitory regular std. dev., $\sigma_{\mathrm{r}}$ & 9.721 & 0.072 \\
\hline Transitory underground std. dev., $\sigma_{\mathrm{u}}$ & 5.951 & 0.092 \\
\hline Transitory correlation, $\rho_{\epsilon}$ & -0.021 & 0.024 \\
\hline Permanent regular std. dev., $\tau_{\mathrm{r}}$ & 17.198 & 0.543 \\
\hline Permanent underground std. dev., $\tau_{\mathrm{u}}$ & 16.446 & 1.052 \\
\hline Permanent correlation, $\rho_{\mu}$ & 0.499 & 0.032 \\
\hline Number of observations & 2517 & \\
\hline Mean log-likelihood & -0.528 & \\
\hline
\end{tabular}

coefficient between the permanent individual effects in the regular and the underground sectors is significantly positive and the temporary correlation is insignificant. This evidence indicates that, when controlling for a number of explanatory variables, men who work many hours in the regular sector also tend to have a larger permanent labour supply to the underground sector.

Based on the results in Table 3, we calculate for each individual in the sample, the underground labour supply elasticities with respect to regular net wage rate, income and underground gross wage rate. The elasticities are calculated for each individual using observed hours if larger than zero and predicted individual hours else, and using predicted 
Table 4

Descriptive statistics of the wage and income elasticities for the labour supply in the untaxed underground sector

\begin{tabular}{|c|c|c|c|c|c|c|}
\hline & \multicolumn{2}{|c|}{$\begin{array}{l}\text { Uncompensated substitution } \\
\text { elasticities }\end{array}$} & \multicolumn{2}{|c|}{$\begin{array}{l}\text { Compensated substitution } \\
\text { elasticities }\end{array}$} & \multirow[t]{2}{*}{ Virtual income } & \multirow[t]{2}{*}{$\begin{array}{l}\text { No. of } \\
\text { observations }\end{array}$} \\
\hline & $\begin{array}{l}\text { Gross wage, } \\
\text { underground } \\
\text { sector }\end{array}$ & $\begin{array}{l}\text { Net wage, } \\
\text { regular sector }\end{array}$ & $\begin{array}{l}\text { Gross wage, } \\
\text { underground } \\
\text { sector }\end{array}$ & $\begin{array}{l}\text { Net wage, } \\
\text { regular sector }\end{array}$ & & \\
\hline $\begin{array}{l}\text { State } 1 \text {, } \\
\qquad h_{\mathrm{R}}>0, h_{\mathrm{U}}>0\end{array}$ & $\begin{array}{l}0.017 \\
(0.007)\end{array}$ & $\begin{array}{l}-0.489 \\
(0.188)\end{array}$ & $\begin{array}{l}0.021 \\
(0.008)\end{array}$ & $\begin{array}{l}-0.487 \\
(0.187)\end{array}$ & $\begin{array}{l}-0.060 \\
(0.042)\end{array}$ & 345 \\
\hline $\begin{array}{l}\text { State } 2 \text {, } \\
\qquad h_{\mathrm{R}}>0, h_{\mathrm{U}}=0\end{array}$ & $\begin{array}{l}0.019 \\
(0.007)\end{array}$ & $\begin{array}{l}-0.566 \\
(0.200)\end{array}$ & $\begin{array}{l}0.022 \\
(0.008)\end{array}$ & $\begin{array}{l}-0.564 \\
(0.200)\end{array}$ & $\begin{array}{l}-0.076 \\
(0.054)\end{array}$ & 707 \\
\hline $\begin{array}{l}\text { State } 3 \\
\qquad h_{\mathrm{R}}=0, h_{\mathrm{U}}>0\end{array}$ & $\begin{array}{l}0.012 \\
(0.006)\end{array}$ & $\begin{array}{l}-0.288 \\
(0.145)\end{array}$ & $\begin{array}{l}0.016 \\
(0.008)\end{array}$ & $\begin{array}{l}-0.287 \\
(0.145)\end{array}$ & $\begin{array}{l}-0.039 \\
(0.034)\end{array}$ & 33 \\
\hline $\begin{array}{l}\text { State } 4 \\
\qquad h_{\mathrm{R}}=0, h_{\mathrm{U}}=0\end{array}$ & $\begin{array}{l}0.014 \\
(0.007)\end{array}$ & $\begin{array}{l}-0.358 \\
(0.182)\end{array}$ & $\begin{array}{l}0.016 \\
(0.008)\end{array}$ & $\begin{array}{l}-0.357 \\
(0.181)\end{array}$ & $\begin{array}{l}-0.041 \\
(0.032)\end{array}$ & 84 \\
\hline All & $\begin{array}{l}0.018 \\
(0.007)\end{array}$ & $\begin{array}{l}-0.521 \\
(0.206)\end{array}$ & $\begin{array}{l}0.021 \\
(0.008)\end{array}$ & $\begin{array}{l}-0.519 \\
(0.206)\end{array}$ & $\begin{array}{l}-0.068 \\
(0.050)\end{array}$ & 1169 \\
\hline
\end{tabular}

Empirical standard deviations are in parentheses.

wages for all individuals. This approach allows us to calculate elasticities in all four states, as defined in Section 2. In Table 4, average and standard deviation of the individual elasticities are shown for the four states.

On average, the own compensated as well as uncompensated elasticity in the underground sector is small, less than 0.02 , and not varying much between the states. The cross-substitution effects, i.e. the elasticities of regular net wages on the underground labour supply, are negative as expected and numerically much larger than the own wage elasticities. The compensated cross wage elasticity is on average about -0.5 , largest among individuals working in the regular sector. ${ }^{15}$ Thus, labour supplies to the regular and labour supply to the underground sector are cross-substitutes. Based on these results, we should expect that an increase in the regular net wage rate, either by an increased gross wage or a reduced marginal tax rate will have numerically fairly large effects on underground labour supply. The estimation results in Table 3 (and the calculated elasticities which are not shown here) also indicate that the cross wage elasticities for regular labour supply, i.e. the elasticities of underground net wages with respect to regular labour supply, are much smaller than the cross wage elasticities in the underground sector. Thus, regular wages seem to have large influence on the underground labour supply while underground wages do not seem to influence regular taxed labour supply. However, due to the small amount of hours worked in the underground sector the absolute change in hours

\footnotetext{
${ }^{15}$ Lacroix and Fortin (1992) find in their analysis for Canada an own wage elasticity for the underground sector of 0.8 in state 1 and 0.3 in their unconstrained model which is closest to the model estimated here. (They do not report own, cross wage and income elasticities for all states because they use observed, not predicted values in the calculation of elasticities.) Thus, their results seem to be more than 10 times larger than ours. Their underground labour supply elasticity with respect to regular net wages -0.8 in state 1 , a result which is fairly close to the results reported in Table 4. The same holds for the income elasticities which are found to be negative but numerically very small. However, Lacroix and Fortin report elasticities for men and women together.
} 
Table 5

Marginal income tax rates in the sample

\begin{tabular}{|c|c|c|c|c|}
\hline \multicolumn{5}{|c|}{ Marginal income tax rate } \\
\hline $7.0 \%$ & $47.2 \%$ & $51.8 \%$ & $65.8 \%$ & Total \\
\hline \multicolumn{5}{|c|}{ Sample proportion, \% } \\
\hline 9 & 21 & 25 & 45 & 100 \\
\hline
\end{tabular}

worked in the underground sector from for example, a tax reduction on work in the regular sector will be small- this is shown in Section 6.

\section{Simulations of tax reductions}

Based on the results in Table 3, several reforms of the tax system can be simulated. The micro-simulations are partial in the sense that they do not include general equilibrium effects and thus, the results from these simulations should be interpreted with care. Further, they are not modelled as budget neutral reforms, but the reforms are designed to give the same initial budget revenue effect in order to facilitate comparisons of the supply effects of different reforms. Similarly, the simulations cannot be extrapolated to the entire economy, since the sample excludes women, self-employed and retired persons, see Section 4. However, the intention of showing these simulations is that they indicate directions, interactions and consequences of the existing tax system. We have chosen to use both the 1994 and 1996 sample in the simulation. Thus, the "before reform" averages in Tables 6 and 7 concern the pooled sample. The Danish income tax system is progressive with four tax segments and three kink points. In 1996, the marginal tax rates on the four segments were $7 \%, 47.2 \%, 51.8 \%$ and $65.8 \%{ }^{16}$ The marginal tax rate distributions for the sample is presented in Table 5.

In order to illustrate the implications of the estimated model, we have simulated two different tax reforms each having an initial effect public revenue of $1 \%$ of GDP. The changes are simulated for each individual and averages are given in Tables 6 and 7. First, a $2 \%$ point decrease in the 'basic state tax rate' which implies a reduction of all marginal tax rates in the second, third and fourth segment of about $1.7 \%$ points. Second, we remove the 'top state tax rate' meaning that the highest marginal tax rates is reduced from $65.8 \%$ to $51.8 \%$, i.e. the third tax kink is removed. Both reforms increase the value of the regular sector net wage rates, but the second reform does not affect the lower income deciles while the effect on the net wages of high income groups is much larger than for Reform 1 . In order to give an indication of these potential distributional differences between the two reforms, we show the supply effects, distributed by educational level. Table 6 shows the initial underground labour supply before the hypothetical reforms and the calculated average change in participation rates, and the unconditional and conditional labour supply. In general, the supply effects in the underground sector of both reforms are small. A reduction of the 'basic tax rate' has a numerically smaller effect on the underground labour

\footnotetext{
${ }^{16}$ A detailed description of the Danish income tax system in 1996 is given in Frederiksen et al. (2001).
} 
Table 6

The change in average participation rate $\left(P_{\mathrm{U}}\right)$ and average predicted weekly labour supply $\left(h_{\mathrm{U}}\right)$ in the underground sectors from tax reforms

\begin{tabular}{|c|c|c|c|c|c|c|c|c|c|}
\hline \multirow{3}{*}{$\begin{array}{l}\text { School } \\
\text { completed }\end{array}$} & \multicolumn{3}{|c|}{ Before reform } & \multicolumn{6}{|c|}{ After reform } \\
\hline & \multicolumn{3}{|l|}{ Level } & \multicolumn{3}{|c|}{$\begin{array}{l}2 \% \text { points lower basic tax rate. } \\
\text { Change in }\end{array}$} & \multicolumn{3}{|c|}{$\begin{array}{l}\text { Removal of the top tax rate. } \\
\text { Change in }\end{array}$} \\
\hline & $\begin{array}{l}P_{\mathrm{U}} \% \\
\text { points }\end{array}$ & $\begin{array}{l}h_{\mathrm{U}} \\
\text { weekly } \\
\text { hours }\end{array}$ & $\begin{array}{l}h_{\mathrm{U}} \mid h_{\mathrm{U}}>0 \\
\text { weekly } \\
\text { hours }\end{array}$ & $\begin{array}{l}P_{\mathrm{U}} \% \\
\text { points }\end{array}$ & $\begin{array}{l}h_{\mathrm{U}} \\
\text { weekly } \\
\text { hours }\end{array}$ & $\begin{array}{l}h_{\mathrm{U}} \mid h_{\mathrm{U}}>0 \\
\text { weekly } \\
\text { hours }\end{array}$ & $\begin{array}{l}P_{\mathrm{U}} \% \\
\text { points }\end{array}$ & $\begin{array}{l}h_{\mathrm{U}} \\
\text { weekly } \\
\text { hours }\end{array}$ & $\begin{array}{l}h_{\mathrm{U}} \mid h_{\mathrm{U}}>0 \\
\text { weekly } \\
\text { hours }\end{array}$ \\
\hline Basic & 26.8 & 0.760 & 2.835 & -0.19 & -0.019 & -0.019 & -0.28 & -0.029 & -0.023 \\
\hline Vocational & 27.4 & 0.646 & 2.356 & -0.22 & -0.022 & -0.023 & -0.52 & -0.055 & -0.041 \\
\hline Academic & 11.8 & 0.244 & 2.064 & -0.22 & -0.022 & -0.023 & -0.91 & -0.091 & -0.099 \\
\hline Total & 23.9 & 0.598 & 2.500 & -0.21 & -0.021 & -0.021 & -0.52 & -0.054 & -0.041 \\
\hline
\end{tabular}

supply than a reduction in the 'top tax rate'. If the 'top tax rate' and thus the third tax kink is removed, the male participation rate in the underground sector is reduced by about $0.5 \%$ points, from $23.9 \%$ to $23.4 \%$.

However, a tax reduction may of course also have effects on labour supply in the regular sector and one should expect that especially for individuals who work in the underground sector the incentive to switch from 'underground' to 'regular' sector work should be large. This is analysed in Table 7. Contrary to the underground labour supply, labour supply in the regular sector seems to be fairly sensitive to tax reductions, in accordance with the elasticities shown in Table 4 . A reduction of the 'basic tax rate' of $2 \%$ increases the taxed labour supply by about $0.3 \mathrm{~h} /$ week. The effects are considerably larger for a tax cut in the 'top tax rate', where the average effect is $1 \mathrm{~h} /$ week. The effect of both reforms increases with educational level. This is in accordance with the results found in Frederiksen et al. (2001) who analyse the supply effects of Danish income tax reforms in an alternative econometric setup (a 'Hausman type model') which does not include the potential interactions effects between taxed and untaxed labour supply. Columns 5 and 7 in Table 7 indicate that the increased labour supply in the regular sector is not mainly caused by a shift from 'underground' to 'regular' sector work. On average, individuals already

Table 7

The change in average predicted weekly labour supply in the regular sector from tax reforms

\begin{tabular}{|c|c|c|c|c|c|c|c|}
\hline \multirow{3}{*}{$\begin{array}{l}\text { School } \\
\text { completed }\end{array}$} & \multicolumn{3}{|c|}{ Before reform } & \multicolumn{4}{|c|}{ After reform completed } \\
\hline & \multicolumn{3}{|l|}{ Level } & \multicolumn{2}{|c|}{$\begin{array}{l}2 \% \text { points lower basic tax rate. } \\
\text { Change in }\end{array}$} & \multicolumn{2}{|c|}{$\begin{array}{l}\text { Removal of the top tax rate. } \\
\text { Change in }\end{array}$} \\
\hline & $\begin{array}{l}P_{\mathrm{r}}^{\mathrm{a}} \% \\
\text { points }\end{array}$ & $\begin{array}{l}h_{\mathrm{r}} \\
\text { weekly } \\
\text { hours }\end{array}$ & $\begin{array}{l}h_{\mathrm{r}} \mid h_{\mathrm{U}}>0 \\
\text { weekly } \\
\text { hours }\end{array}$ & $\begin{array}{l}h_{\mathrm{r}} \\
\text { weekly } \\
\text { hours }\end{array}$ & $\begin{array}{l}h_{\mathrm{r}} \mid h_{\mathrm{U}}>0 \\
\text { weekly } \\
\text { hours }\end{array}$ & $\begin{array}{l}h_{\mathrm{r}} \\
\text { weekly } \\
\text { hours }\end{array}$ & $\begin{array}{l}h_{\mathrm{r}} \mid h_{\mathrm{U}}>0 \\
\text { weekly } \\
\text { hours }\end{array}$ \\
\hline Basic & 78.0 & 28.5 & 29.1 & 0.270 & 0.253 & 0.494 & 0.354 \\
\hline Vocational & 87.6 & 32.9 & 29.8 & 0.347 & 0.319 & 0.968 & 0.642 \\
\hline Academic & 90.2 & 35.0 & 35.8 & 0.458 & 0.451 & 2.173 & 2.140 \\
\hline Total & 85.0 & 31.9 & 30.2 & 0.346 & 0.309 & 1.068 & 0.693 \\
\hline
\end{tabular}

\footnotetext{
${ }^{\mathrm{a}} P_{\mathrm{r}}$ is participation rate in regular sector.
} 
working in the underground sector increase their labour supply marginally less than individuals who do not work in the underground sector before the reform.

Thus, combining the results from Tables 6 and 7, we conclude, that a reduction of the marginal tax rates in Denmark, either a smaller general reduction of almost all marginal tax rates (Reform 1) or a large reduction of the highest marginal tax rates (Reform 2), has fairly small (absolute) effects on labour supply in the underground sector but considerably larger effects on labour supply in the regular sector.

\section{Conclusion}

The paper sets up and estimates a bivariate random effect panel data model for male labour supply in the taxable regular and the non-taxable underground sectors in Denmark. We find that taxes twist the labour supply away from taxed regular to untaxed underground supply since the estimated coefficient to the net wage rate in the regular sector is positive for regular labour supply and negative for underground labour supply. We also find significant correlations of the permanent individual-specific effects in the two sectors. Men who work many hours in the regular sector also tend to work many hours in the underground sector when controlling for all the observed characteristics.

This paper presents the first Danish underground sector labour supply elasticities. The average income elasticity in the underground sector is negative but numerically small and insignificant. The average underground wage elasticity is positive for men, but small, while the average cross wage elasticity, i.e. the elasticity of underground sector labour supply with respect to net wage rate in the regular sector, is significantly negative and numerically much larger than the own wage elasticity. Thus, the net wages in the regular sector have fairly large effects on male underground labour supply.

In order to evaluate the size of the estimated supply effects, two reforms of the tax system are simulated. Both reforms will reduce the initial tax revenue by about $1 \%$ of GDP. The first reform contains a $1.7 \%$ points reduction of almost all marginal tax rates and the second reform a large reduction of the highest marginal tax rates affecting only about half of the male labour force. Both simulations indicate that reducing the income tax rates has very small (absolute) effects on the underground labour supply. However, if the main purpose of a tax reform is to increase the taxed labour supply, the simulations do give arguments in favour of tax cuts in the sense that there are positive effects on labour supply to the regular sector, especially for tax cuts in the upper end of the tax scale.

\section{Acknowledgements}

Financial support from the Danish National Research Foundation and the Danish Research Council (FREJA-program) is gratefully acknowledged. We thank P.J. Pedersen, P. Bingley and three anonymous referees for many helpful comments. The creation of the data set used in the study has been supported financially by the Rockwool Foundation, and the construction of the data set is joint work with the Rockwool Research Unit. The presented analysis is solely the authors' responsibility. 


\section{Appendix A. Sample means for selected variables, 1996}

\begin{tabular}{|c|c|c|c|c|c|c|c|c|c|}
\hline \multirow[t]{2}{*}{ Characteristics } & \multirow{2}{*}{$\begin{array}{l}\% \text { of } \\
\text { total } \\
\text { sample }\end{array}$} & \multicolumn{4}{|c|}{ Participation in the regular sector } & \multicolumn{4}{|c|}{ Participation in the underground sector } \\
\hline & & $\%$ & $\begin{array}{l}\text { Hours } \\
(h \geq 0)\end{array}$ & $\begin{array}{l}\text { Hours } \\
(h \mid h>0)\end{array}$ & $\begin{array}{l}\text { Net wage } \\
\text { rate }\end{array}$ & $\%$ & $\begin{array}{l}\text { Hours } \\
(h \geq 0)\end{array}$ & $\begin{array}{l}\text { Hours } \\
(h \mid h>0)\end{array}$ & $\begin{array}{l}\text { Wage } \\
\text { rate }\end{array}$ \\
\hline Total & 100.0 & 90.0 & 35.6 & 39.6 & 56.4 & 32.3 & 0.8 & 2.5 & 85.4 \\
\hline \multicolumn{10}{|l|}{ Age } \\
\hline $18-24$ & 11.1 & 88.5 & 34.0 & 38.5 & 45.8 & 43.1 & 1.0 & 2.2 & 80.7 \\
\hline $25-39$ & 40.9 & 92.3 & 36.9 & 40.0 & 56.1 & 37.7 & 1.2 & 3.2 & 85.0 \\
\hline $40-59$ & 48.0 & 88.4 & 34.9 & 39.5 & 59.1 & 25.3 & 0.5 & 1.8 & 87.6 \\
\hline \multicolumn{10}{|l|}{ Marital status } \\
\hline Married & 54.8 & 93.0 & 37.2 & 40.1 & 58.9 & 27.3 & 0.6 & 2.1 & 88.1 \\
\hline Cohabiting & 18.9 & 90.1 & 35.4 & 39.3 & 54.5 & 40.3 & 1.3 & 3.2 & 82.2 \\
\hline Single & 26.3 & 83.7 & 32.5 & 38.8 & 52.2 & 37.1 & 0.9 & 2.5 & 83.6 \\
\hline \multicolumn{10}{|c|}{ School completed } \\
\hline Basic & 32.7 & 83.8 & 33.2 & 39.7 & 51.7 & 34.6 & 0.8 & 2.4 & 80.2 \\
\hline Vocational & 45.6 & 92.9 & 36.8 & 39.7 & 55.5 & 38.8 & 1.0 & 2.7 & 89.9 \\
\hline Academic & 21.7 & 93.3 & 36.7 & 39.4 & 64.8 & 15.4 & 0.3 & 1.9 & 78.9 \\
\hline
\end{tabular}

\section{References}

Ahn, N., De la Rica, S., 1997. Underground economy in Spain: an alternative to unemployment? Applied Economics 29 (3), $733-743$.

Allingham, M., Sandmo, A., 1972. Income tax evasion: a theoretical analysis. Journal of Public Economics 1, $323-338$.

Amemiya, T., 1985. Advanced Econometrics. Harvard Univ. Press. Cambridge, Chap. 10.

Cowell, F., 1985. Tax evasion with labor income. Journal of Public Economics 26, 19-35.

Cowell, F., 1990. Cheating the government. The Economics of Evasion. The MIT Press, Cambridge, Massachusetts.

Duncan, A., 1990. Labour supply decisions and non-convex budget sets: The case of national insurance contribution in the UK. Institute of Fiscal Studies. WP90-7.

Feige, E., 1989. The underground economies. Tax Evasion and Information Distortion. Cambridge Univ. Press, Cambridge.

Fortin, B., Lemieux, T., Fréchette, P., 1990. An empirical model of Labor Supply in the Underground Economy. NBER WP 3392.

Frederiksen, A., Graversen, E., Smith, N., 2001. Overtime work, dual job holding and taxation, WP01-7, Department of Economics, Aarhus School of Business, Aarhus, IZA DP no. 323, IZA, Bonn.

Graversen, E., 1998. Labour Supply and Work Incentives, PhD thesis 1998-2, Department of Economics. University of Aarhus.

Hassink, W., van Ours, J., 1995. Hiring and firing; an empirical analysis using gross flow data. Preliminary paper. Hausman, J., Ruud, P., 1984. Family labor supply with taxes. The American Economic Review 74 (2), $242-248$. Isachsen, A., Samuelsen, S., Ström, S., 1985. The behaviour of tax evaders. In: Gaertner, W., Wenig, A. (Eds.), The Economics of the Shadow Economy. Springer Verlag, Berlin, pp. 227-244.

Lacroix, G., Fortin, B., 1992. Utility-based estimation of labour supply functions in the regular and irregular sectors. Economic Journal 102, 1407-1422.

Lemieux, T., Fortin, B., Fréchette, P., 1994. The effect of taxes on labour supply in the underground economy. The American Review 84 (1), 231-254.

Pedersen, S., Smith, N., 1998. 'Black' labour supply and 'black' wages. Nationaløkonomisk Tidsskrift 136, 289-314 (In Danish).

Schneider, F., Enste, D.H., 2000. Shadow economies: Size, causes, and consequences. Journal of Economic Literature $38,77-114$. 
van Eck, R., Kazemier, B., 1988. Features of the hidden economy in the Netherlands. The Review of Income and Wealth 34 (3), 251-273.

Wolff K., 1990. The shadow economy: a microanalysis of black labour supply in the FRG-The influence of gender, social networks and other socioeconomic factors on black participation, wages and hours. Sfb 3working paper no. 324. Presented at the fifth congress of the European economic association. 